\title{
Use of Metadiscourse in the Persuasive Writing of Nigerian Undergraduates
}

\author{
Shehu Muhammad Korau ${ }^{1} \&$ Muhammad Mukhtar Aliyu ${ }^{1}$ \\ ${ }^{1}$ Department of English and Literary Studies, Bauchi State University, Gadau- Nigeria \\ Correspondence: Muhammadmukhtar Aliyu, Department of English and Literary Studies, Bauchi State University, \\ Gadau- Nigeria.
}

Received: March 2, 2020

Accepted: March 22, 2020

Online Published: March 26, 2020

doi: 10.5539/elt.v13n4p104

URL: https://doi.org/10.5539/elt.v13n4p104

\begin{abstract}
Persuasive writing is a very important prerequisite for undergraduates in their academic life endeavour. For the students to effectively compose good persuasive writing, they need to understand and employ metadiscourse appropriately in their writing. However, a large number of Nigerian undergraduates face lots of challenges in using metadiscourse in their writing. Therefore, this study investigated the use of metadiscourse in the persuasive writing of Nigerian undergraduates, by examining the relationship between the frequency of metadiscourse used and the persuasive writing quality. The participants of the study are second-year students of English in one of the Nigerian Universities. The data used in the study were collected through the participants' written persuasive essays. The essays were analyzed by highlighting all the metadiscourse used in the texts. The findings indicate that the participants' persuasive essays have a low deployment of metadiscourse which also correlates with their persuasive writing quality. It was observed that almost all the metadiscourse markers were underutilized by the participants such as endophoric markers, evidential, code glosses, hedges and self-mention. Some other metadiscourse were left out in some of the participants' persuasive essays. The study highlights some benefits of the use of metadiscourse and some implications that would improve the teaching and learning of metadiscourse, particularly in the Nigerian setting.
\end{abstract}

Keywords: metadiscourse use, Nigerian undergraduates, persuasive writing

\section{Introduction}

Persuasive writing is one of the very essential skills for undergraduates' academic success. They are engaged in various acts of academic writing which are mostly persuasive ranging from assignments, reports, term papers and examinations. Their academic achievement in universities is mostly facilitated and determined by the quality of their writing (Zakaria \& Abdul Malik, 2018). Therefore, to cope with various challenges of academic writing, undergraduates need to develop their persuasive and critical thinking skills which are essential components of academic writing. Works of literature have indicated that Nigerian undergraduates face numerous problems with their academic writing ranging from lexis, structures and punctuations (Ngadda \& Nwoke, 2014). Nonetheless, a particular area that has not been much investigated by many scholars in evaluating the academic writing of Nigerian undergraduates is metadiscourse. For students to compose a good persuasive written discourse, they need to be aware of and employ appropriate metadiscourse devices within the written discourse. Metadiscourse is a fundamental linguistic means that helps writers to route the movement of their written ideas as well as address their outlook to the readers (Tan \& Eng, 2014).

Few studies were conducted to investigate the use of metadiscourse devices in the writing of Nigerian undergraduates (Haruna, Ibrahim, Haruna, Ibrahim \& Yunus, 2018). However, there seems to be an absence of studies that specifically investigates the use of metadiscourse in persuasive writing or compare the use of metadiscourse and the quality of the students' writing. Therefore, this study is aimed at investigating the use of metadiscourse in the persuasive writing of the Nigerian undergraduates and examining the relationship between the frequency of the metadiscourse used and the students' writing quality.

\subsection{Objectives of the Study}

The general objective of this research work is to examine the use of Metadiscourse elements in the persuasive writing of Nigerian undergraduates. The following are the specific objectives of the study. 
1. To investigate the use of metadiscourse in the persuasive writing of Nigerian undergraduates.

2. To examine the relationship between the frequency of metadiscourse used and the persuasive writing quality of the undergraduates.

\section{Literature Review}

Harris (1959) was the first person to define the term Metadiscourse "as a way of understanding language use which helps writers or speakers to guide the receivers' understanding of a text" (cited in Hyland, 2005). According to Hyland, (2017), Metadiscourse means how language is used with the reader or audience in mind based on how writers can aid them to process and comprehends what is written or said. It is an audience base filter which aids to show how the author intends a message to be understood through making a commentary on it. This is as important as depicting attention toward the discourse in this manner discloses the writer's awareness to the audience and the extent and kind of his need for expansion, guidance, clarification and interaction. As a result of the successful organization of these rhetorical resources aids to achieve communicative and social objectives, readers' assessments also reveal how an author is connected and understand the setting being discussed. Thus, Metadiscourse reveals acquaintance with the target audience and provide a link between discourse and context.

Hyland and Tse (2004) maintained that Metadiscourse devices are essential resources use to indicate how a text or discourse is organized, clarify and simplify difficult jargons for audience or readers. In other words, effective employment of Metadiscourse markers will make text accessible and readable among the prospective audiences. Moreover, the understanding and usage of Metadiscourse are observed to be important to both undergraduate students and the expected readers of the students' discourse (Zakaria \& Abdul Malik, 2018). Teachers can assess and guide the students on how Metadiscourse is appropriately employed in a text through the reading of the students' works.

Metadiscourse use has been extensively investigated in undergraduate academic writings in international contexts. A comparison of the use of Metadiscourse in a good and poor undergraduate essay was carried out by Intaraprawat and Steffensen (1995) and revealed that good essays engaged more interactional Metadiscourse while weak essays employed more of the interactive. Moreover, well-written essays deployed a more and wide range of Metadiscourse forms than weaker ones. This made the researchers determine that Metadiscourse use is a cornerstone as far as well written essays are concerned. Similarly, Letsoela, (2013) investigated the Metadiscourse used in undergraduate research reports and the study revealed that the participants of the study deployed more interactive than interpersonal Metadiscourse. Meanwhile, Tan \& Eng (2014) examined the metadiscourse use in the persuasive writing of Malaysian undergraduate students. The findings revealed that both groups of the participants (High experience participants and Low experience participants) used more interactional Metadiscourse, while the HEP writers used both interactive and interactional Metadiscourse. The result also discovered that transition and engagement markers have the highest frequency among the Metadiscourse markers. However, the use of boosters and hedges between the two groups of writers were pretty different. The HEP appeared to be able to balance the use of hedges and boosters unlike the LEP's use of hedges was so negligible compared to the use of boosters. Maybe, this could be the HEP writers were so much aware of the important need to persuade their readers in a clearer and precise manner.

Moreover, the study of Metadiscourse is not confined to just undergraduates. The study also takes care of and investigated postgraduate academic writing. In a study carried out by Hyland, (1999), Metadiscourse used comparison was made between introductory textbooks for tertiary students and research articles. The study revealed that even though, both of the texts unveiled a higher use of textual metadiscourse, the research articles exhibited a greater increase in the use of the interpersonal metadiscourse. The result was not new neither surprising, due to the persuasive nature of research articles which need more use of the interpersonal Metadiscourse. Moreover, Hyland, (2004) investigated the use of Metadiscourse in 240 masters and doctoral dissertations of many disciplines (Applied linguistics, Biology, business studies, Computer science, Electronic Engineering and Public Administration). The study revealed that Metadiscourse use is an essential rhetorical device in academic writing more especially at the postgraduate level where students deployed slightly more interactive than interpersonal devices. It further stated that $\mathrm{PhD}$ writers deployed more Metadiscourse than master students. This could be due to the length of $\mathrm{PhD}$ text is wider than that of masters' text, this more Metadiscourse element should be in place to persuade and convince supervisors and other readers of the text. Lastly, the findings revealed that more Metadiscourse devices are used in a dissertation in soft science because establishing proof in the soft science field is more difficulty, as a result, more Metadiscourse should be used to establish credibility in their texts. Furthermore, Mina and Biria (2017) conducted their study on exploring 
interactive and interactional Metadiscourse markers in discussion sections of social and medical science articles. The findings revealed that the authors of social science articles used evidential, frame markers, and transition markers more frequently than the authors of medical science. However, there was no difference between the two groups in the use of endophoric and code glosses. The study finally revealed that the social science authors used interactive Metadiscourse markers more, while medical science authors deployed more interactional metadiscourse makers in their texts.

\subsection{Model of Metadiscourse}

According to Vande (1985) and Hyland (2005) in Ntereke and Ramoroka (2017), Hyland's framework owns insights from the systemic functional grammar that views language use as performing three macro-functions which Hyland referred to as the ideational, interpersonal and textual functions. The ideational function is mainly concerned with the propositional content, while the textual function deals with how language is used to organize discourse and lastly, the interpersonal function has to do with the use of language to encrypt interaction that can allow authors to engage with audiences or readers.

The Hyland's model contents two levels of interactions; the interactive and the interactional levels. The interactive elements help a writer to have an organized and coherent propositional content. These elements are transitional markers, frame makers, endophoric markers, evidential and code glosses. Interactional elements allow a writer's voice. These elements include self -mention, hedges, boosters, engagement markers and attitude markers. The interactional elements embroil a reader in the text argument and show the author's perspective towards the content of the proposition. Hyland used the idea of Halliday's (1970) tenor, he relates to the notion of the author's voice and position. Hyland similarly points out interactional elements refer to the tenor of the discourse that is mainly concerned with guiding the level of personality in a discourse (Hyland 2004).

The table below contains the details of the two classifications of the Metadiscourse, which is adopted in this research.

Table 1. Hyland (2005) Interpersonal model of Metadiscourse; interactive markers

\begin{tabular}{|c|c|c|}
\hline Macro category & Subcategory & Examples \\
\hline \multirow[t]{3}{*}{ Transition } & I. Addition & $\begin{array}{l}\text { and, furthermore, moreover, also, } \\
\text { in addition }\end{array}$ \\
\hline & II. Comparison & $\begin{array}{l}\text { In contrast, however, but, on the } \\
\text { other hand, on the contrary }\end{array}$ \\
\hline & III. Consequence & $\begin{array}{l}\text { Consequently, after all, then thus, } \\
\text { therefore, as a consequence }\end{array}$ \\
\hline \multirow[t]{8}{*}{ Frame markers } & I. to sequence & (in) Chapter X, first, next, lastly, I \\
\hline & & begin with, I end with \\
\hline & & All in all, at this point, in \\
\hline & II. to label stages & conclusion, on the whole \\
\hline & & My focus, goal, objective is to, I \\
\hline & III. to announce goals & seek to, my purpose is to \\
\hline & & Back to, in regard to, return to turn \\
\hline & IV. to shift topic & to \\
\hline Endophoric markers & & noted above/see figure/in section \\
\hline Evidentials & & According to X (1990) states \\
\hline \multirow[t]{3}{*}{ Code glosses } & & Namely/e.g/such as/in other \\
\hline & & word/that is/to put it simply/ for \\
\hline & & example/for instance \\
\hline
\end{tabular}

Hyland (2005) classified interactive Metadiscourse into five main categories that consist of transition, frame markers, endophoric markers, evidential and code glosses. Two out of the five main categories included some subcategories to mark their importance in a text; each category carries out a particular special function. 
Transition contains a number of elements mainly conjunctions applied to show an additive, contrastive and consequential step in a text as against the external world. Furthermore, frame markers refer to discourse boundaries and items of schematic discourse structure that include elements use to sequence, to label discourse stages, to announce text goals and to present topic shift. Endophoric markers produce more materials that are available and essential to the reader in rediscovering the writer's goals. This is done by referring to other parts of the discourse. Evidentials are linguistic statements and ideas took from another text. For example, Reza (2017) stated that code Glosses are linguistic markers that provide additional information for a clear understanding of the preferred meaning of the writer by the readers. For example, this is called, such as, in other words, this can be defined.

Table 2. Hyland (2005) model of interactional Metadiscourse

\begin{tabular}{ccc}
\hline Micro category & Subcategory & Examples \\
\hline Hedges & I. Epistemic verbs & May/might/it mostly \\
& II. Probability adverbs & Probably/perhaps/maybe... \\
III. Epistemic expressions & Unlikely, unclear \\
Booters & I. Emphatics & Certainly, demonstrate, really \\
& II. Amplifying adverbs & Totally, always in fact, definitely \\
III. Cognitive verbs & It is clear that \\
Attitude markers & I. Deontic verbs & Unfortunately/remarkably \\
& II. Attitudinal adjectives & It is absurd/it is surprising \\
Self -mentions & III. Cognitive verbs & I feel/ I think/I agree/I believe \\
Engagement markers & First person pronouns & I, me, my, mine \\
& I. Second person pronouns & You, your, yourself \\
& II. Interjection & by the way, you may notice \\
& III. Imperative verbs & Consider, note that, see, look at \\
& IV. Necessity models & must have to, should \\
\hline
\end{tabular}

The interactional Metadiscourse is classified into five main categories and subcategories attached to four out of the five. Hedges, the first on the table has the following subcategories; epistemic verbs, probability adverbs and epistemic expressions. These elements signal the author's reluctance to pageant propositional information. The second on the table are boosters which include emphatics, amplifying adverbs and cognitive verbs that represent a certainty and emphasize the force of propositions. Thirdly is the attitudinal markers that have the following as its subcategories; deontic verbs, attitudinal adverbs, attitudinal adjectives and cognitive verbs indicating surprise, force, importance and approval; they also indicate author's appraisal of propositional information. Fourthly is the self -mention that includes first-person pronouns which indicate the presence of the author in the text. Lastly, is the engagement markers that contain second personal pronouns, interjection, imperative verbs and necessary models as subcategories that clearly refer to the readers by engaging them as the text participants or important part of the discourse through the use of second-person pronouns, questions and imperative statements (Hyland, 2001).

\section{Method}

In this study, persuasive essays written by second-year undergraduates were analyzed to investigate the use of Metadiscourse and the relationship between the frequencies of the Metadiscourse and the quality of the essays.

\subsection{Research Design}

The correlational research design is adopted in this research work. This research work involved a textual analysis of undergraduates' persuasive writing to determine the relationship between metadiscourse frequency and the participants' writing quality.

\subsection{Participants}

The participants of the study were 56 second-year undergraduates from a Department of English and Literary Studies in one of the universities in Northern Nigeria. They are purposefully sampled out because it's believed that they have attained a particular stage of writing proficiency in the English language as a result of rigorous training received in their first and second years of university study. 


\subsection{Writing Task}

A writing topic was given to the participants and asked to individually write a persuasive essay of about $350-400$ for or against the topic (see Appendix A). The persuasive based essay was given with the view that it will attract much deployment of Metadiscourse.

\subsection{Data Collection Procedure}

The researchers obtained permission from the Department from which the participants come. Consent was obtained from the participants. After that, the participants wrote the essays and submitted to the researchers.

\subsection{Text Analysis}

The persuasive essays written by the participants were analyzed and the metadiscourse markers were identified and categorized. For reliability, the corpora were manually analyzed word to word and were checked by two experienced raters. This is to cross-check the detailing of metadiscourse distribution in the written persuasive essay of the participants. Both raters have a $\mathrm{PhD}$ in English and have ten-year experience of teaching English in tertiary institutions in Nigeria. After the analysis of the data, the total number of metadiscourse deployed by the participants in the written persuasive essays were determined. The entire metadiscourse markers deployed by the students were examined to know how they were used. The researchers identified the correct and the incorrect metadiscourse used in the persuasive written essays and these were cross-checked by the raters to confirm the correct and incorrect number of metadiscourse used in the written essays.

\section{Results and Discussion}

\subsection{Frequency of the Metadiscourse Used}

To achieve the first research objective of the study that is, to investigate the use of metadiscourse in the undergraduates' persuasive writing, the participants' written essays were analyzed and the metadiscourse devises used were identified. The metadiscourse was categorized into 10 groups. The metadiscourse with the highest number of frequency and percentage is frame markers and transition with the frequency of 75 and 15.85 per cent each; followed by boosters with 68 . However, the metadiscourse with the least number of frequencies is 'hedges' with a frequency of 20 , followed by engagement markers with 30 frequencies and self-mention with 37 frequencies.

The table below indicated the frequency and percentage of metadiscourse as they appeared in the persuasive written essays of the undergraduates.

Table 3. The use of Metadiscourse in the written texts.

\begin{tabular}{cccc}
\hline $\boldsymbol{S} / \boldsymbol{N}$ & Metadiscourse & Frequency & Percentage \\
\hline $\mathbf{1}$ & Transition & 75 & 15.85 \\
$\mathbf{2}$ & Frame markers & 75 & 15.85 \\
$\mathbf{3}$ & Endophoric markers & 45 & 9.51 \\
$\mathbf{4}$ & Evidential & 43 & 9.09 \\
$\mathbf{5}$ & Code glosses & 42 & 8.87 \\
$\mathbf{6}$ & Hedges & 20 & 4.23 \\
$\mathbf{7}$ & Boosters & 68 & 14.37 \\
$\mathbf{8}$ & Attitude markers & 38 & 8.03 \\
$\mathbf{9}$ & Self-mention & 37 & 7.82 \\
$\mathbf{1 0}$ & Engagement markers & 30 & 6.34 \\
& Total & $\mathbf{4 7 3}$ & $\mathbf{1 0 0}$ \\
\hline
\end{tabular}




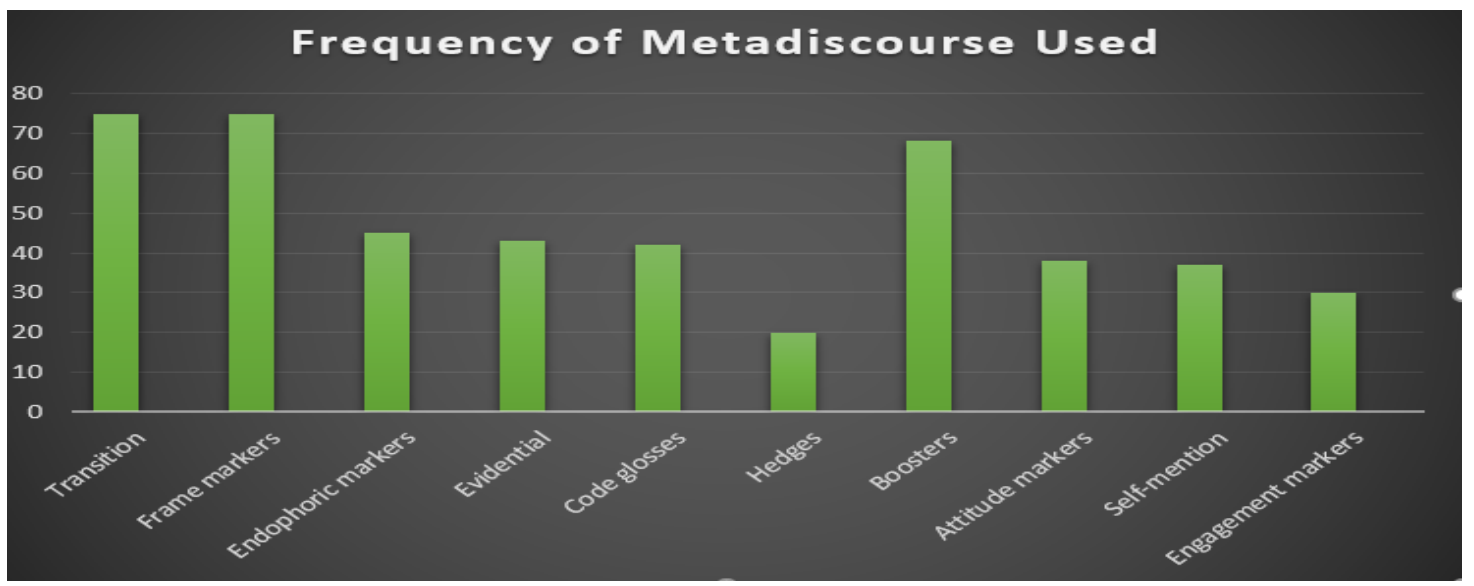

Figure 1. Frequency of Metadiscourse Used

The above chart indicated a vivid picture of how the Metadiscourse elements have occurred in the persuasive writing of the undergraduates.

The data were further analysed to identify the correct and incorrect usage of metadiscourse in the persuasive writing of the students. Out of the total number (473) of Metadiscourse elements used in the participants' persuasive writing, 227 metadiscourse were used correctly, while 246 metadiscourse were used incorrectly. The following is the breakdown of each element: transition has 35 correct and 40 incorrect, frame markers has 40 correct and 35 incorrect, endophoric markers 25 correct and 20 incorrect, evidential has 19 correct and 24 incorrect, code glosses have 20 correct and 22 incorrect, hedges have 10 correct and 10 incorrect, boosters have 30 correct and 38 incorrect, attitude markers has 18 correct and 20 incorrect, self-mention has 17 correct and 20 incorrect and lastly engagement markers has 13 correct and 17 incorrect. This makes the total number of 227 correct and 246 incorrect metadiscourse elements used by the undergraduates in their persuasive writing text. The table below presents the correct and incorrect number of metadiscourse elements that appeared in the persuasive writing of the participants.

Table 4. Correct and incorrect Metadiscourse used

\begin{tabular}{|c|c|c|c|}
\hline \multirow[t]{2}{*}{$\underline{\mathbf{S} / \mathbf{N}}$} & \multirow[t]{2}{*}{ Metadiscourse } & \multicolumn{2}{|c|}{ Frequency } \\
\hline & & $\underline{\text { Correct }}$ & $\underline{\text { Incorrect }}$ \\
\hline 1 & Transition & 35 & 40 \\
\hline 2 & Frame markers & 40 & 35 \\
\hline 3 & Endophoric markers & 25 & 20 \\
\hline 4 & Evidential & 19 & 24 \\
\hline 5 & Code glosses & 20 & 22 \\
\hline 6 & Hedges & 10 & 10 \\
\hline 7 & Boosters & 30 & 38 \\
\hline 8 & Attitude markers & 18 & 20 \\
\hline 9 & Self-mention & 17 & 20 \\
\hline \multirow[t]{2}{*}{10} & Engagement markers & 13 & 17 \\
\hline & Total & 227 & 246 \\
\hline
\end{tabular}

Therefore, looking at the data presented on the table, it could be seen that the first stated objective of the study that says 'to investigate the use of Metadiscourse in the persuasive writing of Nigerian undergraduates' has been achieved. Considering the total number (473) of metadiscourse used in the persuasive writing of the undergraduates and the correct and incorrect number of metadiscourse used in their persuasive writing 227/246, 
it could be concluded that the majority of the participants do not have sufficient knowledge or not understand how to use metadiscourse markers in their persuasive writing. This is because out of the 19,600 words produced in the persuasive written essays of the participants, only 473 Metadiscourse markers were realized. This is obvious as almost all the metadiscourse markers were underutilized by the participants. Metadiscourse markers like endophoric markers, evidential, code glosses, hedges self-mention and a lot more markers that help a writer to persuade, convince and engage the audiences or readers to be part of the text were seriously underutilized. Other metadiscourse devices were completely left out in some of the participants' written persuasive essays. These findings support the findings of previous studies, like that of Tan (2011) who observed that many second language writers experience difficulties in using Metadiscourse in their writing activities. Similarly, Haruna, Ibrahim, Haruna, Ibrahim and Yunus (2018) affirmed that many Nigerian undergraduates were not exposed to the Metadiscourse and their importance in writing, this led the students to write the way they speak.

\subsection{Relationship between the Frequency of Metadiscourse Used and the Persuasive Writing Quality}

To achieve the second objective of the study that is, to examine the relationship between the undergraduates' use of Metadiscourse and the quality of their persuasive writing. The participants' essays were analyzed using the Analytical Scale of Argumentative Writing (ASAW) developed by Nimehchisalem, (2010). It is a heuristic scale with five components with a total score of 100: 1. Content 20marks, 2. Organization 20 marks, Vocabulary 20 marks, language convention 20 marks and overall effectiveness 20 marks. Each of the components has the following five categories: excellent, competent, modest, basic and very limited (see appendix for the description of the components).

Based on their scores, the participants were grouped into three; high 100-70, moderate $69-40$ and low 39-0. Then the researchers determined which group has the highest number of Metadiscourse used in their writing and which has the highest number of correct Metadiscourse used in their writing.

The results of the analysis of the undergraduates' use of Metadiscourse in the persuasive written essays presented in the table below palpably indicated that the writing quality of many of the participants is low which correlates positively with the use of metadiscourse. The scores have been classified into three; the first is high 100-70 that none of the falls under the high-level scores, while moderate 60-40 has 16 participants fall within and lastly the law 39-0 which has 40 participants fall within the lowest scores category.

Table 5. Categories of scores based on the persuasive writing performance

\begin{tabular}{ccc}
\hline Category of scores & Participants & Metadiscourse used \\
\hline High 100-70 & & \\
Moderate 60-40 & 16 & 298 \\
Low 39-0 & 40 & 175 \\
\hline
\end{tabular}

The below extract is from one of the participants' texts that is within the low score category. The essay has some number of Metadiscourse markers but mostly used incorrectly. In the whole text, there are several metadiscourse devices which have not been used total by the participant such as hedges, self-mention that are seriously in need to make the text-friendly to readers. As a result of the misuse and absence of some Metadiscourse markers and other errors, most of the participants' texts fall under the low score category.

\section{Extract A}

a. ...Some lecturers use this end of semester examination to threaten some student or give them carryover why because they refuse to comply with them just of recent a girl was impregnated by her lecturer just to pass here examination with good grade but it all ends up in a very big mess why because the lecturer refuse and reject the pregnancy...

$b$. ...The another reason that want the University examination to burn the current government does not consider what you read or what certificate you have they only consider who is your father or where you belong to...

c. ...We as students, we will face the different challenges apart from the studies which the students did not having his time rest at some time...

The following Extract is for participants' texts that fall within moderate scores,

\section{Extract B}

a. Examinations, as we all know it, have emerged to be the main facet of modern education in the eve-changing landscape of academia. In an education infrastructure that is as unpredictable as the clouds... 
b. Furthermore, exams are unhealthy for students. When students hear of upcoming exams, it usually means that when they go home that night they feel depressed and worried about how well they will do...

c. Conclusively, while examinations have been so far a legitimate means of testing students' abilities and at time a means of motivation to students, the drawbacks with regards to pressuring student...

Thus, the second objective of the study which is to examine the relationship between the frequency of metadiscourse and the persuasive writing quality of the undergraduates is also achieved. Looking at the analyses presented in Table 5 above, the majority (40) of the participants got low scores of 39-0, while few numbers (16) of the participants got the moderate scores of 60-40. These findings indicate that there is a correlation between the frequency of metadiscourse and the quality of the undergraduates' persuasive writing. This means that the lower the number of Metadiscourse used in writing the lower the writing quality of the participants. This could be seen from the table 5 above that palpably indicated how the few ones who obtained moderate scores have used 298 metadiscourse markers while those at the lower scores with 40 participants, but only managed to use 175 metadiscourse markers in their texts. This revealed that the more metadiscourse a writer deployed correctly in his/her text the more the quality of the text.

Moreover, the participants have used very few numbers of Metadiscourse in their persuasive writing this made the majority of their writing low in quality. This result is not surprising at all because the participants wrote about 19,600 words and only 473 words are said to be Metadiscourse. This indicates that there is very a low utilization of Metadiscourse in the persuasive writing of the undergraduates, which in turn affects the quality of their writing. The result also indicates that metadiscourse markers play significant roles in helping students to write, to persuade and successfully get their messages to the target audience.

The data analyzed revealed that the higher the correct number Metadiscourse used in the persuasive writing the better the writing. This is because metadiscourse is of great importance as far as writing is concerned (Hyland, 2005). This result has supported the previous studies on metadiscourse from the earliest time to the present day (Tan \& Eng, 2014). Metadiscourse is essential resources use to indicate how a text or discourse is organized, clarify and simplify difficult jargon for the audience or readers (Hyland \&Tse, 2004).

\section{Conclusion}

The objective of the study is to investigate the use of metadiscourse and its relationship with the quality of persuasive writing of the Nigerian undergraduates. The results revealed a positive relationship between the frequency of Metadiscourse used and the quality of persuasive writing of the undergraduates. The findings indicate that the higher the number of correct metadiscourse used the better the persuasive written texts of the participants. The findings also revealed that most of the participants have a low deployment of Metadiscourse in their writing performance which correlates with the low quality of written texts.

The results of this study have offered an insight into how the persuasive writing of Nigerian undergraduates experienced low deployment Metadiscourse which is possibly the reason for having low quality. The results also revealed that Metadiscourse helps a lot in having a very good written text that serves as a melting pot for both the writers and the audiences. Teachers and lecturers should create students' awareness of the importance of metadiscourse devices in helping writers to logically present ideas to convince readers. They should also emphasize the teaching and correct usage of metadiscourse in the students' academic writing.

There are some limitations to the study. It is carried out with second-year students from a University in the Northern part of Nigeria. Similarly, the research work is restricted only to undergraduates; it did not include a vast array of students such as postgraduates and pre-university students. Therefore, further studies could take care of how postgraduate and pre-university students use metadiscourse in their academic writing.

\section{Acknowledgements}

This study is sponsored by TETFUND Nigeria in 2019. We are indeed grateful.

\section{References}

Ghahremani Mina, K. \& Biria, R. (2017). Exploring interactive and interactional metadiscourse markers in discussion sections of social and medical science articles. International Journal of Research in English Education, 2(4), 11-29. https://doi.org/10.29252/ijree.2.4.11

Halliday, M. A. (1970). Language structure and language function. New horizons in linguistics, 1, 140-165.

Haruna, H. H., Ibrahim, B., Haruna, M., Ibrahim, B. \& Yunus, K. (2018). Metadiscourse in Students' Academic Writing: Case Study of Umaru Musa Yar'adua University and Al-Qalam University Katsina. International Journal of English Linguistics, 8(7), 83-92. https://doi.org/10.5539/ijel.v8n7p83 
Harris, Z. S. (1959). The transformational model of language structure. Anthropological Linguistics, 27-29.

Halliday, M.A.K. (1973). Explorations in the functions of language. London: Edward Arnold.

Hyland, K. (1999). Talking to students: Metadiscourse in introductory course books. English for Specific Purposes, 18(1), 3-26. https://doi.org/10.1016/S0889-4906(97)00025-2

Hyland, K. (2004). Disciplinary interactions: Metadiscourse in L2 postgraduate writing. Journal of Second Language Writing, 13(2), 133-151. https://doi.org/10.1016/j.jslw.2004.02.001

Hyland, K. (2005). Metadiscourse. New York: Continuum.

Hyland, K. (2001). Humble servants of the discipline? Self-mention in research articles. English for Specific Purposes, 20(3), 207-226.https://doi.org/10.1016/S0889-4906(00)00012-0

Hyland, K. \& Tse, P. (2004). Metadiscourse in academic writing: A reappraisal. Applied Linguistics, 25(2), 156-177.https://doi.org/10.1093/applin/25.2.156

Hyland, K. \& Tse, P. (2005). Hooking the reader: A corpus study of evaluative that in abstracts. English for Specific Purposes, 24(2), 123-139.https://doi.org/10.1016/j.esp.2004.02.002

Hyland, K. (2005b). Metadiscourse: Mapping interaction in academic writing. University of London, UK http://ojs.ub.gu.se/ojs/index.php/njes/article/view/417

Hyland, K. (2005). Representing readers in writing: Student and expert practices. Linguistics and Education, 16(4), 363-377.https://doi.org/10.1016/j.linged.2006.05.002

Hyland, K. (2008). As can be seen: Lexical bundles and disciplinary variation. English for Specific Purposes, 27(1), 4-21.https://doi.org/10.1016/j.esp.2007.06.001

Hyland, K. (2017). What is it and where is it going? Journal of pragmatics, 113, 16-29.https://doi.org/10.1016/j.pragma.2017.03.007

Hyland, K. \& Jiang, F. K. (2017). Is academic writing becoming more informal? English for Specific Purposes, 45, 40-51.https://doi.org/10.1016/j.esp.2016.09.001

Intaraprawat, P. \& Steffensen, M. S. (1995). The use of metadiscourse in good and poor ESL essays. Journal of Second Language Writing, 4(3), 253-272.https://doi.org/10.1016/1060-3743(95)90012-8

Letsoela, P. M. (2013). Interacting with readers: Metadiscourse features in national university of Lesotho undergraduate students' academic writing. International Journal of Linguistics, 5(6), 138.https://doi.org/10.5296/ijl.v5i6.4012

Ngadda, Z. Y. \& Nwoke, A. (2014). An analytical study of errors in the written English of undergraduate engineering students, ATBU a case study. Journal of Education and Practice, 5(38), 8-16.

Nimehchisalem, V. (2010). Developing an analytic scale for argumentative writing of students in a Malaysian public university. Unpublished Doctoral Dissertation, Universiti Putra Malaysia, Serdang, Malaysia.

Ntereke, B. B. \& Ramoroka, B. T. (2017). Reading competency of first-year undergraduate students at the University of Botswana: A case study. Reading \& Writing, 8(1), 1-11.https://doi.org/10.4102/rw.v8i1.123

Tan, H. (2011). Metadiscourse features in the persuasive essays of undergraduate writers. Unpublished $\mathrm{PhD}$ thesis, Universiti Putra Malaysia.

Tan, H. \& Eng, W. B. (2014). Metadiscourse Use in the Persuasive Writing of Malaysian Undergraduate Students. English Language Teaching, 7(7), 26-39.https://doi.org/10.5539/elt.v7n7p26

Zakaria, M. K. \& Malik, F. A. (2018). Metadiscourse in academic writing of pre-university Arab Students at the International Islamic University Malaysia (IIUM). In MATEC Web of Conferences (Vol. 150, p. 05086). EDP Sciences. https://doi.org/10.1051/matecconf/201815005086 


\section{Appendix A}

\section{Writing Task on Undergraduates' Use of Metadiscourse in Persuasive Writing}

In not less than five paragraphs (which include an introductory paragraph, developmental paragraphs and a concluding paragraph), write a persuasive essay on why end-of-semester examinations should be banned in your university. Provide at least three convincing reasons to explain your stand on the topic. To support your stand, you can quote relevant sources, use tables, statistics, and your life-experiences.

\section{Appendix B}

\section{Analytical Scale of Argumentative Writing}

\begin{tabular}{|c|c|c|}
\hline Score & 1. Content & Grade (level) \\
\hline $15-20$ & $\begin{array}{l}\text { Effectively introduces the claim(s), maturely provides an in-depth or extensive account of } \\
\text { relevant data in support of the claim(s), backs the warrants, accounts for reburtals and may } \\
\text { employ qualifiers }\end{array}$ & A (Excelleat) \\
\hline $12-14$ & $\begin{array}{l}\text { Presents a reasonably mature and extensive account of relevant claims and data, but at times } \\
\text { lacks adequate backing }\end{array}$ & B (Competent) \\
\hline $10-11$ & Presents relevant claims and data, but the data sound immature and are not well-elaborated & $\mathrm{C}$ (Modest) \\
\hline $8-9$ & Presents claims, data, warrants and backings, some of which may be irrelevant & D (Basic) \\
\hline $0-7$ & No response $\mathrm{O}$ : only makes a number of claims, some of which may be irrelevant & F (Very limited) \\
\hline Score & 2. Organization & Grade (level) \\
\hline $15-20$ & $\begin{array}{l}\text { Well-organized introduction/narration/division, body and conclusion; sentences skillfully } \\
\text { linked; an internal logic clearly showing writer's purpose and flow of ideas }\end{array}$ & A (Excellent) \\
\hline $12-14$ & $\begin{array}{l}\text { Reasonably well-arranged introduction, confimmation and conclusion; sentences connected } \\
\text { reasonably well; sometimes hard to follow the line of thought because of the gaps between a } \\
\text { few ideas }\end{array}$ & B (Competent) \\
\hline $10-11$ & $\begin{array}{l}\text { Introduction/conclusion: brief lacking, despite certain redundant ideas, easy to follow } \\
\text { writer's line of thought and purpose; sentences linked well but cases of wrong counections } \\
\text { evident }\end{array}$ & C (Modest) \\
\hline $8-9$ & $\begin{array}{l}\text { No introduction/conclusion; evidence of some basic form of cohesion but in case of } \\
\text { complicated ideas, lack of cohesion; despite a few incoherent sentences, a simple pattern of } \\
\text { thought evident }\end{array}$ & D (Basic) \\
\hline $0-7$ & Lacking an introduction/conclusion; no/vain attempts to create cohesion; OR no response & F (Very limited) \\
\hline Score & 3. Vocabulary & Grade (level) \\
\hline $15-20$ & $\begin{array}{l}\text { Appropriate use of simple-complex/technical words, phrases, collocations, idioms, or figures } \\
\text { of speech; few incorrect forms; skilful use of synonyms/antonyms to avoid repetition }\end{array}$ & A (Excellent) \\
\hline $12-14$ & $\begin{array}{l}\text { Occasional incorrect word forms, phrases, or collocations; mostly using simple words; use of } \\
\text { synonyms/antonyms to avoid repetition but still a few repeated words }\end{array}$ & B (Competent) \\
\hline $10-11$ & $\begin{array}{l}\text { Incorrect word forms, phrases, or collocations in almost every other sentence; sometimes } \\
\text { even lacking simple words to communicate; OR repeating the same words all over the essay }\end{array}$ & $C$ (Modest) \\
\hline $8-9$ & Incorrect word forms, phrases, or collocations in almost all sentences & $\mathrm{D}$ (Basic) \\
\hline $0-7$ & No response or a collection of irrelevant words & $\mathrm{F}$ (Very limited) \\
\hline Score & 4. Language conventions & Grade (level) \\
\hline $15-20$ & $\begin{array}{l}\text { Few negligible slips; variety of simple-complex structures; form getting meaning across very } \\
\text { skillfully, very skilful control over spelling, capitalization and punctuation }\end{array}$ & A (Excellent) \\
\hline $12-14$ & $\begin{array}{l}\text { Occasional errors; mostly simple structures; form still getting meaning across, occasional } \\
\text { spelling, capitalization or pumctuation problems not blurring meaning }\end{array}$ & B (Competent) \\
\hline $10-11$ & $\begin{array}{l}\text { Almost one error every other sentence; form bluring meaning sometimes, some spelling, } \\
\text { capitalization, or punctuation problems blurring meaning, spelling, capitalization, or } \\
\text { pumctuation problems in almost all sentences blurning meaning }\end{array}$ & C (Modest) \\
\hline $8-9$ & A collection of garbled sentences and fragments, confusing rather than communicating & D (Basic) \\
\hline $0-7$ & No response fragments; spelling, capitalization punctuation problems in almost all the essay & $\mathrm{F}$ (Very limited) \\
\hline Score & 5. Overall effectiveness & Grade (level) \\
\hline $15-20$ & $\begin{array}{l}\text { Very skilful and effective presentation and justification of argumeats through a highly } \\
\text { engaging, correct, clear, appropriate and/or omate style; task requirements skillfully fulfilled; } \\
\text { written well over the word limit }\end{array}$ & A (Excellent) \\
\hline $12-14$ & $\begin{array}{l}\text { Effectively presenting and justifying arguments through an reasonably engaging, correct, } \\
\text { clear and appropriate style; task still fulfilled reasonably well; written over to the word limit }\end{array}$ & B (Competent) \\
\hline $10-11$ & $\begin{array}{l}\text { A reasonable ability in presenting arguments but through a simple, fairly correct, clear and } \\
\text { appropriate style, task requirements almost fulfilled: written around the word limit }\end{array}$ & $\mathrm{C}$ (Modest) \\
\hline $8-9$ & $\begin{array}{l}\text { Lacking a reasonable ability in presenting arguments through a monotonous, usually } \\
\text { incorrect, unclear and inappropriate style; task partially fulfilled; written below the word limit }\end{array}$ & $\mathrm{D}$ (Basic) \\
\hline $0-7$ & $\begin{array}{l}\text { No ability to present arguments; incorrect, unclear and inappropriate style; task not fulfilled; } \\
\text { written far below the word limit }\end{array}$ & F (Very limited) \\
\hline
\end{tabular}

\section{Copyrights}

Copyright for this article is retained by the author(s), with first publication rights granted to the journal.

This is an open-access article distributed under the terms and conditions of the Creative Commons Attribution license (http://creativecommons.org/licenses/by/4.0/). 